\title{
Ortaokul Öğretmenlerinin Destekleme ve Yetiştirme Kurslarına Yönelik
}

Tutumlarının İncelenmesi*

\section{Investigation of Secondary School Teachers' Attitudes towards Supporting and Training Courses}

\author{
Cemal AKÜZÜM** Mehtap SARAÇOĞLU**
}

Makalenin geliş tarihi: 13.05.2018

Kabul tarihi: 30.05 .2018

\section{$\ddot{O} \mathbf{z}$}

$\mathrm{Bu}$ araştırma, resmi devlet ortaokullarında görev yapan öğretmenlerin Destekleme ve Yetiştirme Kurslarına ilişsin görüşlerini ortaya koymaya yönelik bir çalışmadır. Nicel araştırma türlerinden tarama modeli kullanılarak yapılan çalışmanın evrenini, Diyarbakır ili merkez ilçelerinde (Bağlar, Kayapınar, Sur, Yenişehir) bulunan 381 ortaokulda görev yapan 4081 öğretmen oluşturmaktadır. Örneklemini ise, araştırmanın desenine uygun olarak, ortaokullarda görev yapan öğretmenler arasından amaçlı örnekleme yöntemlerinden olan "ölçüt örnekleme" yöntemi ile seçilen 536 öğretmen oluşturmaktadır. Öğretmenlerin destekleme ve yetiştirme kurslarına ilişkin görüşleri, araştırmacılar tarafından geliştirilen 3 faktör ve 22 maddeden oluşan "Destekleme ve Yetiştirme Kurslarına Yönelik Tutum Ölçeği” kullanılarak alınmıştır. Çalışmadan elde edilen veriler SPSS ve AMOS paket programları aracılığı ile analiz edilmiştir. Araştırma bulguları; öğretmenlerin destekleme ve yetiştirme kurslarına yönelik tutumlarının en yüksek düzeyde olduğu boyutun, bu kursların akademik yönden hem öğrencilere hem de öğretmenlere sağladığı katkılar yönünde olduğunu göstermektedir. Buna karşılık, kurslara katılımın özel bir zaman ayırmayı gerektirmesinin ortaya çıkardığı sosyal yaşama olan etkileri boyutunun en düşük düzeydeki tutumları yansıttığı da görülmektedir. Branş değişkenine göre; Türkçe, Matematik, Fen Bilimleri, Sosyal Bilgiler ve Yabancı Dil branşlarındaki öğretmenlerin, Diğer branşındaki öğretmenlere nazaran destekleme ve yetiştirme kurslarının akademik katkısına ilişkin tutumlarının daha yüksek olduğu görülmüştür.

Anahtar Kelimeler: Destekleme ve yetiştirme kursları, ortaokul, öğretmen, ders dışı faaliyetler.

\begin{abstract}
This research is aimed at revealing the opinions of the teachers working in official state secondary schools relating to the Supporting and Training Courses. The universe of work done using the screening model of quantitative research types, consists of 4081 teachers working in 381 secondary schools in Diyarbakir province in central districts (Bağlar, Kayapınar, Sur, Yenişehir). The sample, according to the study design, consist of 536 teachers selected by means of "criterion sampling" which is one of the purpose sampling methods among the teachers working in secondary schools. The opinions of the teachers about the support and training courses were

\footnotetext{
* Çalışma, 19-21 Ekim 2017 tarihinde Antalya'da düzenlenen The International Social Sciences and Education Conference (ISSEC)'de sözlü bildiri olarak sunulmuştur.

** Doç. Dr., Dicle Üniversitesi Ziya Gökalp Eğitim Fakültesi Temel Eğitim Bölümü, Diyarbakır/Türkiye, cemal.akuzum@dicle.edu.tr

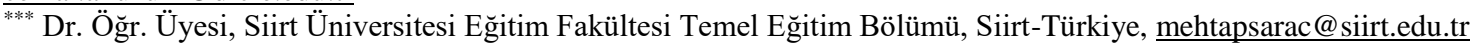


obtained by using the "Attitude Scale for Supporting and Cultivation Courses" consisting of 3 factors and 22 items developed by the researchers. Data obtained from the study were analyzed via SPSS and AMOS packet programs. The findings of the research show that the attitudes of teachers towards support and training courses are at the highest level, indicating that these courses are in the direction of contributions to both the students and the teachers in the academic direction. On the other hand, it appears that the need to allocate a special time to the courses reflects the lowest level of attitudes towards social life. According to the branch variable, teachers in Turkish, Mathematics, Science, Social Sciences and Foreign Language branches have higher attitudes towards academic contribution of support and training courses than teachers in other branches.

Keywords: Supporting and training courses, secondary school, teachers, extracurricular activities.

\section{GİRIŞ̧}

Eğitim kurumları, eğitim-öğretim sürecinde önceden belirlenmiş olan hedeflerin öğrencilere kazandırılması amacıyla her türlü etkinliği geliştirip uygulamaya koyabilir. Öğretim etkinliklerinin amaçlı ve tertipli bir biçimde gerçekleştirilmesi ölçüsünde verimli olabilen okul ve sınıf ortamlarında öğrenciler, öğrenmeye motive olurlarsa daha fazla çalışarak daha iyi öğrenebilirler (Krajcik \& Blumenfeld, 2006). Ancak hedeflenen kazanımların çevresel ya da bireysel faktörlerden dolayı öğrenciye yeterli düzeyde ulaşamamasından ötürü ekstra bir öğretim faaliyetine gidilebilmektedir. $\mathrm{Bu}$ faaliyetlerden biri olan Destekleme ve Yetiştirme Kursları (DYK), eğitim-öğretim kurumlarında öğrencilere devlet tarafindan ücretsiz olarak verilen ek öğretim hizmetidir. Destekleme ve yetiştirme kursları yönergesi (MEB, 2016); Yaygın Eğitim Kurumları Yönetmeliği (RG. 27587-21/5/2010), Millî Eğitim Bakanlığı Ortaöğretim Kurumları Yönetmeliği (RG. 28758-7/9/2013) ve Millî Eğitim Bakanlığ1 Okul Öncesi Eğitim ve İlköğretim Kurumları Yönetmeliği (RG. 29072-26/7/2014) hükümlerine dayanılarak hazırlanmıştır.

Destekleme ve Yetiştirme Kursları, 23.09.2014 tarih ve 4145909 sayılı Milli Eğitim Bakanlığı Örgün ve Yaygın Eğitimi Destekleme ve Yetiştirme Kursları Yönergesi kapsamında dershanelerin dönüşüm sürecine girmesi ile birlikte 2014-2015 eğitim öğretim yllında Türkiye'deki ortaokul ve liseler ile lise mezunları için halk eğitim merkezlerinde uygulanmaya başlamıştır. Destekleme ve Yetiştirme Kursları Yönergesi’nde; kursun amaçları, kapsamı, kurs açma ve kapatma esasları ile kurs süreleri, sınıf mevcutlarındaki asgari ve azami öğrenci sayıları, kurs merkezleri, kurslardaki öğretim faaliyetleri, yönetim unsurları ve teftişin nasıl yapılacağı yer almaktadır (MEB, 2016). 2017-2018 eğitim-öğretim yılı 2. Döneminde belirlenen 12 pilot il ve ilçelerinde ilkokul 3. ve 4. sınıf öğrencileri için sadece Türkçe ve Matematik dersleri için destekleme ve yetiştirme kursları açılmıştır. Destekleme Kursları öğrenci/kursiyer ve velilerden gelen istek üzerine (bir dersten 10 öğrencinin müracaatıyla) örgün eğitim müfredatındaki bütün dersler için açılabilir. Kurslar, iki dönemi eğitim-öğretim faaliyetlerinin devam ettiği süreçte, bir dönemi ise yaz tatilinde olmak üzere üç dönem olarak planlanmaktadır. Kurslar, hafta içi ders saatlerinden sonra yapılabileceği gibi hafta sonları da 
yapılabilmektedir. Öğrencilerin hem bu kurslarda hem de derslerde yararlanmaları için MEB tarafından Eğitim Bilişim Ağ (EBA) uygulamaya konulmuştur. EBA, bütün öğretmen ve öğrencilerin kullanımına ücretsiz olarak sunulan çevrimiçi bir sosyal eğitim platformudur. DYK'ya öğrenciler, Eğitim Bilişim Ağı (EBA) modülü üzerinden istediği dersleri ve bu derslere girmesini istedikleri öğretmenleri seçerek başvuru yapmaktadır. Kurslarda görev almak isteyen öğretmenler de benzer şekilde EBA üzerinden başvuru yapmaktadır. Kurs merkezi okul ise, öğrenci ve öğretmen başvuruları göz önünde bulundurularak ders grupları oluşturulmaktadır. Okuldaki öğretmenlerle ihtiyacın karşılanamaması durumunda başka okullardan öğretmenlere ders verilebilir. Kursların açılması, kapanması, öğrenci sayısı, devamsızlık, ders saatleri gibi kurslarla ilgili bütün detaylar DYK Yönergesinde ayrıntılı olarak belirtilmiştir (MEB, 2017).

Alan yazını incelendiğinde, ülkemizde 2014-2015 öğretim yılından beri uygulanmaya başlanan destekleme ve yetiştirme kurslarının farklı yönlerine odaklanan bazı çalışmaların yapıldığı görülmektedir. Bu çalışmalarda; destekleme ve yetiştirme kurslarının amacı, kapsamı, kazanımları, öğretim yöntemleri, ölçme ve değerlendirme süreçleri ile yaşanan sorunların (Akkaya, 2017); kursa katılan öğrencilerin görüşleri temelinde DYK uygulama sürecinde edinilen kazanımların (Biber, Tuna, Polat, Altunok ve Küçükoğlu, 2017); DYK'ya katılan öğrencilerin spora katılım motivasyonlarının (Bingöl, 2017); örgün ve yaygın eğitimi destekleme ve yetiştirme kurslarında karşılaşılan sorunlar ve kursun paydaşlara olumlu katkılarının (Bozbayındır ve Kara, 2017); DYK uygulamaları, karşılaşılan sorunlar ve iyileştirilmesine yönelik önerilerin (Canpolat, 2017); destekleme ve yetiştirme kurslarının uygulamaya konma süreci, yararları ve yaşanan sorunların (Demir Başaran ve Narinalp Yıldız, 2017); destekleme ve yetiştirme kurslarının işleyişi ve bu kurslarda yaşanan sorunlara ilişkin çözümlerin (Dönmez, Pekcan ve Tekçe, 2016); destekleme ve yetiştirme kurslarının yap1, süreç ve iklim boyutlarının (Ergün, 2017); hafta sonu kurslarının kazanımları, öğretim yöntemi, uygulamadaki sıkıntılar ve çözüm önerilerinin (Göksu ve Gülcü, 2016); destekleme ve yetiştirme kurslarının öğrenciler açısından yararları ve önemi ile, ilgi ve motivasyonlarının (İncirci, İlğan, Sirem ve Bozkurt, 2017); DYK'nın değerlendirilmesi, motivasyona etkisi, ders performansına etkisi ve kursların dezavantajlı yanlarının (Nartgün ve Dilekçi, 2016); sosyal uyumsuzluk, bireysel katkı ve olumsuz öğrenci algılarının (Uğurlu, 2017); DYK kurslarında kullanılan yöntemler, kullanılan materyaller, öğretmen katkıları, öğrenciye olan katkıları ve kursların olumsuz yönlerinin (Ünsal ve Korkmaz, 2016) ele alındığı görülmektedir.

Okul sonrası yapılan kurslar, yurt dışındaki araştırmacılar için de önemli bir araştırma konusu olmuştur. $\mathrm{Bu}$ araştırmaların özellikle Amerika Birleşik Devletlerinde yoğunlaştığı dikkati çekmektedir. Ders dışı faaliyetler, 19. yüzyılda Amerika Birleşik Devletleri'nde başlamıştır (Massoni, 2011). Yurtdışında "extracurricular activities (müfredat dışı faaliyetler)" terimi, düzenli (zorunlu) okul müfredatının dışında gerçekleşen tüm etkinlikleri ifade etmektedir. Genellikle, okul dışı faaliyetler 
gönüllüdür, okul yetkilileri tarafindan onaylanır, desteklenir, mezuniyet için akademik bir kredi taşımaz ve öğrenciler katılımları için not almazlar (Holloway, 1999; Lunenburg \& Ornstein, 2008). $\mathrm{Bu}$ faaliyetler okul saatleri dışında, ancak okul ortamında verilir. Okulla ilişkili olmayan müfredat dış1 faaliyetler bu tanıma dâhil değildir. Ders dışı aktiviteler Amerika Birleşik Devletleri'ndeki birçok okulda sunulmaktadır ve normal okul müfredatının bir parçasını oluşturmayan çok çeşitli etkinliklerden oluşabilir. Çoğu okul, bu etkinliklere öğrencilerin katılımı için özgür bir seçim imkânı tanır, ancak birçok özel okul, bir veya daha fazla ders dışı faaliyeti öğrencileri için zorunlu bir gereklilik haline getirir; böyle bir gerekliliğin her şeyden önce "çok yönlü” bir öğrenci yaratmaya yardım ettiğine inanılır (Stoltzfus, 2007). Müfredat dışı etkinliklerin eğitim üzerindeki ilk etkisi davranıştır. Müfredat dışı etkinliklere katılan öğrencilerin davranış problemleri azalmıştır. Sporda, tatbikatlarda, pratiklerde ve rutinlerde disiplin gösterirler. Öğrenciler bu şeyleri doğru bir şekilde uyguladıklarında iyi davranışları için ödüllendirilirler ve başarılarından gurur duyarlar. Sahip oldukları gururdan dolayı, daha iyi bir sayg1, benlik saygısı ve kendine güven kazanırlar (Massoni, 2011). Birleşik Devletler genelindeki devlet okulu öğrencileri çok çeşitli ders dışı etkinliklere katılırlar: okullar arası ve okul içi atletik programlar; hizmet; müzik, sanat ve drama organizasyonları; ve akademik ve mesleki kulüpleri gibi.

Ders dışı aktiviteler çeşitli nedenlerden dolayı dostluklar için en uygun ortamı sağlar. Etkinlikler çoğunlukla özel ilgi alanına dayalı olarak seçilir ve üyeler etkinliklerinde ortak deneyimleri paylaşır ve bu ortamlarda arkadaş olma ihtimalini artırır. Birçok etkinlikte karşılaşılan, empati, yakınlık ve iletişimin artmasıyla (örneğin, diğer kişilerin sahip olduğu çıkarları öğrenmek veya bir guruba ait hissetmek, dostluk ilişkisi kurmak ve güçlendirmek gibi) beceri geliştirme için firsatlar da vardır (Knifsend \& Juvonen, 2017). Lauver (2002), kentlerin yoksulluktan etkilenen mahallelerinde yaşayan çocuklara okul sonrası programların etkilerini değerlendirmeye yönelik, sosyo-ekonomik seviyesi düşük mahallelerde okul sonrası programlara başvuran 10-14 yaş arası 227 öğrenci ile yürüttüğü çalışmasında, öğrenciler okuldan sonra spor, sanat, dans ve diğer sosyo-kültürel faaliyetlere yönlendirilmiştir. Öğretmenlerin, velilerin ve öğrencilerin büyük bir kesimi okul sonrası programları özellikle çocukları zararlı alışkanlıklardan korumasından dolayı yararlı bulunmakla birlikte, yapılan bu çalışmaların öğrencilerin akademik başarılarını ve test notlarını da arttırdığı görülmüştür. Hock, Pulvers, Deshler ve Schumaker (2001), öğrenme güçlüğü çeken veya akademik başarı düzeyi vasat öğrencileri kapsayan, okul sonrası tutor (özel öğretmen) eğitiminin etkisine yönelik yaptıkları deneysel çalışmalarında, öğrenme güçlüğü çeken veya akademik başarısı vasat olan öğrenciler üzerinde uygulanan tutor destekli eğitimin, eğitime devam eden öğrencilerde başarı sağlandığı tespit edilmiştir. Miranda (2001), müfredat dışı programların öğrencilerin sosyalleşmesine, ders başarılarına ve okula ilişkin algılarına etkisine yönelik çalışmasında, müfredat dışı programların genellikle spor ve sanat alanlarında yapıldığını; müzik, resim, drama, okul gazetesi ve okul kulüpleri şeklinde uygulandığını 
belirtmiştir. Müfredat dışı programların etkileri incelendiğinde, öğrencilerde olumlu davranış değişiklikleri, iyi notlar, okulu bitirme, daha az okul bırakma, başarılı yetişkinler olma, sosyalleşme, girişimcilik gibi yönlerden öğrencilerde olumlu etkileri olduğu tespit edilmiştir.

Ders dış1 etkinliklere katılım risk altındaki öğrencilere yardımcı olur (Holloway, 1999). Mahoney ve Cairns (1997), okul temelli ders dışı faaliyetlere katılım ile erken okul terk etme arasındaki ilişkiyi incelemek amacıyla, boyuna yapılan değerlendirmelerle yedinci sınıftayken mülakata alınan ve her yıl on ikinci sınıfa kadar takip edilen 392 ergenle (206 kı, 186 erkek) tamamladığı çalışmalarında, risk altındaki öğrenciler arasında okuldan ayrılma oranının, daha önce katılmamış olanlar ile karşılaştırıldığında ders dışı aktivitelere katılan öğrenciler için belirgin bir şekilde daha düşük olduğunu ortaya çıkarmıştır. Okuldaki ders dışı faaliyetlerle meşgul olmanın, hem erkekler hem de kızlardaki okuldan erken ayrılma oranlarının düşmesi ile bağlantılı olduğu görülmüsstür. $\mathrm{Bu}$ tür katılımların, marjinal öğrencilere, okullarıyla olumlu ve gönüllü bir bağlantı kurma imkânı sağladığı tespit edilmiştir. Buna karşılık, genellikle okuldan ayrılma önleme programları ve düzeltici eğitim gibi risk altındaki öğrencilerin ihtiyaçlarını karşılamak için kullanılan diğer stratejiler öğrencilerin açıkları üzerine odaklanır ve sapma gruplarının oluşumunda bir katalizör görevi görür. Araştırmacılar, ders dışı etkinliklere katılımın, öğrenci-okul bağlantısını korumak ve güçlendirmek suretiyle risk altındaki öğrenciyi destekleyebileceğine kuvvetle inanmaktadır (Holloway, 1999). Başka araştırmalarda ise, ders dışı etkinliklerin ilk etkisinin öğrencilerin davranışları üzerinde etkili olduğu, ders dışı aktivitelere katılan öğrencilerin davranış problemlerinin azaldığı, yüksek notların ve okula yönelik olumlu tutumun, ders dışı faaliyetlerin öğrenciler üzerindeki ikinci etkisi olduğu (Massoni, 2011); el sanatları ve müzik gibi ders dış1 etkinliklere katılımın öğrencilerde akademik başarı, içselleştirme, iyi davranışlar ve çalışma becerilerinin gelişimine katkılarının olduğu (Metsäpelto ve Pulkkinen, 2012); okul sonrası kurslara katılımın dolaylı olarak akademik başarının artmasına yol açan okul ve okul değerlerine artan bağlılığa yol açtığı gözlemlenmiştir (Holloway, 1999).

Uluslararası alanyazınında, daha çok özel kurslara yönelik çalışmalara yer verildiği görülmektedir. Ayrıca yabancı ülkelerdeki okul sonrası kursların daha çok sportif ve sanatsal aktivitelere yönelik olarak yapıldığı anlaşılmaktadır. Bu kursların, ders çalışmalarından çok çalışan ebeveynlerin evde olmadığı zamanlarda çocukların zararlı alışkanlıklardan ve ortamlardan korunmasına yönelik düşünülmüş faaliyetler olarak görülmektedir (Canpolat, 2017). Özellikle sosyoekonomik yönden dezavantajlı gençleri spor, sanat ve kültürel aktivitelerle zararlı alışkanlıklardan korumaya yöneliktir (Knifsend \& Juvonen, 2017). Bu bilgilerden hareketle, destekleme yetiştirme kursları sadece sınav başarısına odaklanmayıp, sanatsal, sportif ve kültürel etkinliklere yoğunlaşmalıdır, bu durumun akademik başarıyı da beraberinde getireceği düşünülmektedir. Dolayısıyla, destekleme ve yetiştirme kurslarının öğrencilerin ilgi ve yetenekleri kapsamında 
yapılacak bir planlamayla, etkinliklerde spor, müzik, sanat, kodlama, tiyatroya daha çok yer vererek akademik başarılarının ve okula bağlılıklarının arttırılabileceği öngörülmektedir.

Sonuç olarak, Milli Eğitim Bakanlığı tarafından 2014 yılından itibaren okullarda uygulamaya konulan destekleme ve yetiştirme kurslarının etkililiğine yönelik olarak kursta görev alan öğretmenlerin ne düşündükleri kursların daha iyi bir noktaya gelmesi için yapılacak düzenlemeler için önemli bir veri seti sağlayabilir. Milli Eğitim Bakanlığı'nın 2015-2016 eğitim öğretim yılı verilerine göre, Destekleme ve Yetiştirme Kurslarına yaklaşık 9 milyon öğrenci başvuru yapmış ve yaklaşık 630 bin öğretmen kurslarda görev almıştır. Yapılan ücret teşvikiyle hem öğretmen hem de idareci açısından cazip hale getirilmiştir. Ancak yeni bir uygulama olması nedeniyle aksayan yönlerinin olması yani birtakım sorunların yaşanması kaçınılmaz görülmektedir. Bu sorunlara yönelik çözüm önerilerinin geliştirilmesi, kursların bireysel ve akademik katkılarıyla sosyal etkilerinin incelenmesi ilgili kursların daha verimli olmasına katkı sağlayacaktır.

\section{Araştırmanın Amacı:}

$\mathrm{Bu}$ araştırmanın temel amacı, resmi devlet ortaokullarında görev yapan öğretmenlerin Destekleme ve Yetiştirme Kurslarına yönelik tutumlarını incelemektir. Bu temel amaç doğrultusunda aşağıdaki sorulara yanıt aranmıştır:

1. Öğretmenlerin, destekleme ve yetiştirme kurslarına yönelik tutumları hangi düzeydedir?

2. Öğretmenlerin destekleme ve yetiştirme kurslarına yönelik tutumları;
a. Cinsiyet,
b. Yaş,
c. Mesleki k1dem
d. Branş değişkenlerine göre anlamlı farkl1lık göstermekte midir?

\section{YÖNTEM}

\section{Araştırma Modeli}

$\mathrm{Bu}$ çalışma, nicel araştırma türlerinden tarama modeli kullanılarak yapılmıştır. Tarama araştırması, "bir konu ya da olaya ilişkin katılımcıların görüşlerinin ya da ilgi, beceri, yetenek, tutum gibi özelliklerinin belirlendiği” çalışmalardır (Büyüköztürk, Kılıç-Çakmak, Akgün, Karadeniz ve Demirel, 2009). Bu araştırma kapsamında da öğretmenlerin Destekleme ve Yetiştirme Kurslarına yönelik tutumları, ölçek yoluyla elde edilen verilere dayanarak betimlenmeye çalışılmıştır.

\section{Evren ve Örneklem}

Araştırmanın evrenini, Diyarbakır ili merkez ilçelerinde (Bağlar, Kayapınar, Sur, Yenişehir) bulunan 381 ortaokulda görev yapan 4081 öğretmen oluşturmaktadır. Örneklemini ise, araştırmanın desenine uygun olarak, ortaokullarda görev yapan öğretmenler arasından amaçlı örnekleme 
yöntemlerinden olan "ölçüt örnekleme" yöntemi ile seçilmiştir. Bu çalışmanın temel ölçütlerini, Milli Eğitim Bakanlığı'na bağlı resmi ortaokullarda görev yapma ile destekleme ve yetiştirme kurslarında görev alma ölçütleri oluşturmaktadır. Bu temel ölçütler doğrultusunda, dört merkez ilçede destekleme ve yetiştirme kurslarının devam ettiği okullar tespit edilerek toplam 536 öğretmene ölçek dağıtılmış, uygun şekilde doldurulmayan ölçekler ayıklandıktan sonra toplam 435 ölçek değerlendirmeye alınmıştır. Araştırmaya katılan öğretmenlerin demografik nitelikleri Tablo 1'de sunulmuştur.

Öğretmenlerin cinsiyete göre dağılımına bakıldığında, kadın öğretmenler grubun \%38.9'unu ( $\mathrm{f}=169)$ temsil ederken, erkek öğretmenler ise grubun \%61.1'ini $(\mathrm{f}=266)$ temsil etmektedir. Yaş değişkenine göre, öğretmenlerin \%32.2'si (f=140) 30 ve daha az yaş grubunda yer alırken, \%48.7'si ( $\mathrm{f}=212$ ) 31-40 yaş grubunda, \%19.1' $\mathrm{i}(\mathrm{f}=83)$ ise 41 ve üzeri yaş grubunda yer almaktadır. Mesleki kıdem değişkenine göre öğretmenlerin \%46.9'u (f=204) 10 yıl ve daha az mesleki kıdeme sahipken, \%41.4'ü (f=180) 11-20 yıl mesleki kıdeme sahip olup, \%11.7'si (f=51) ise 21 yıl ve üzeri mesleki kıdeme sahiptir. Branş değişkenine göre ise, araştırmaya katılan öğretmenlerin \%19.5’i (f=85) Türkçe, \%19.3'ü (f=84) Matematik, \%12.9'u (f=56) Fen Bilimleri, \%12.4'ü (f=54) Sosyal Bilimler, \%12.'si (f=52) Yabancı Dil, \%9.2'si (f=40) DKAB ve \%14.7'si (f=64) Diğer (Görsel Sanatlar, Müzik, Beden Eğitimi ve Spor vb.) branşlarda görev yaptıkları görülmektedir (Tablo 1).

Tablo 1

Araştırmaya Katılan Öğretmenlerin Demografik Nitelikleri

\begin{tabular}{llcc}
\hline Demografik Nitelik & Gruplar & $\mathrm{N}$ & $\%$ \\
\hline \multirow{2}{*}{ Cinsiyet } & Kadın & 169 & 38.9 \\
& Erkek & 266 & 61.1 \\
Yaş & 30 yaş ve daha az & 140 & 32.2 \\
& $31-40$ yaş & 212 & 48.7 \\
& 41 yaş ve üzeri & 83 & 19.1 \\
Mesleki Kıdem & 10 yıl ve daha az & 204 & 46.9 \\
& $11-20$ yıl & 180 & 41.4 \\
& 21 yıl ve üzeri & 51 & 11.7 \\
& Türkçe & 85 & 19.5 \\
Branş & Matematik & 84 & 19.3 \\
& Fen Bilimleri & 56 & 12.9 \\
& Sosyal Bilimler & 54 & 12.4 \\
Toplam & Yabancı Dil & 52 & 12 \\
& DKAB & 40 & 9.2 \\
& Diğer & 64 & 14.7 \\
& & 435 & 100 \\
\hline
\end{tabular}




\section{Veri Toplama Arac1}

Öğretmenlerin destekleme ve yetiştirme kurslarına ilişkin görüşlerini alabilmek için, araştırmacılar tarafından geliştirilen "Destekleme ve Yetiştirme Kurslarına Yönelik Tutum Ölçeği”" kullanılmıştır. Ölçeği geliştirmek için madde oluşturma süreci detaylı bir şekilde alan yazın taraması yapılarak ve araştırmacılar tarafından geliştirilen benzer değerlendirme araçları (İncirci, İlğan, Sirem \& Bozkurt, 2017; Uğurlu \& Aylar, 2017) incelenerek gerçekleştirilmiştir. Madde havuzu toplam 34 madde içermiştir. Ölçek uygulanmadan önce, ölçeğin görünüş ve kapsam geçerliğini sağlamak için eğitim bilimleri alanında 4 uzmanın görüşlerine başvurulmuştur. Uzmanlardan gelen dönütlere dayalı olarak ölçekten 6 madde silinmiştir. Uygulama öncesinde ölçekte toplam 28 madde yer almıştır.

Destekleme ve Yetiştirme Kurslarına Yönelik Tutum Ölçeğinin faktör yapısı açımlayıcı faktör analizi (AFA) ve doğrulayıcı faktör analizi (DFA) ile gerçekleştirilmiştir. Açımlayıcı faktör analizi ile değişkenler arasındaki ilişkilerden hareketle faktörler bulunurken; doğrulayıcı faktör analizi ile de değişkenler arasındaki ilişkiye dair daha önce saptanan hipotez test edilmiştir (Büyüköztürk, 2002). AFA için SPSS, DFA için de AMOS yazılımları kullanılmıştır.

Birbirleri ile ilişkili değiş̧kenleri bir araya getirerek ve aralarındaki ilişkiyi dikkate alarak (Field, 2009) az sayıda yeni ve kavramsal olarak anlamlı faktörler elde etmek için temel bileşen analizi kullanılarak açımlayıcı faktör analizi (AFA) yapılmıştır. Öncelikle, 435 öğretmenden toplanan verilerin açımlayıcı faktör analizine uygun olup olmadığına bakılmıştır. Sırasıyla, Kaiser-Meyer-Olkin (KMO) değeri ve Barlett Küresellik Testi (BTS) bu amaçla dikkate alınmıştır (Field, 2009). Destekleme ve Yetiştirme Kurslarına Yönelik Tutum Ölçeği için KMO katsayısı .876 olarak hesaplanmıştır. Barlett Küresellik Testi (BTS) sonuçları incelendiğinde (Ki Kare = 3319.334; df =231; $\mathrm{p}<.05$ ), verilerin faktör analizine uygun olduğu görülmektedir (Çokluk, Şekercioğlu ve Büyüköztürk, 2010; Field, 2009). Faktör sayısını belirlemek için özdeğerin 1'den büyük olması, açıklanan toplam varyansın oranı ve yamaç-birikinti grafiğidir (Field, 2009). İlk çözüm, Destekleme ve Yetiştirme Kurslarına Yönelik Tutum Ölçeğinin üç-faktör yapısı toplam varyansın \%54.39'unu açıkladığını göstermektedir. Daha sonrasında, .40’tan daha düşük olan yükler çıktıda silinmiştir (Field, 2009). Bileşenler matrisi analiz edildiğinde, 28 maddenin tamamının .53'ten daha fazla faktör yükü olduğu gözlemlenmiş ve çoğunlukla da ilk faktörde toplanmıştır. Bu yükleme ilk faktörün varyansın çoğunu açıkladığını göstermiştir (Field, 2009). Bir sonraki aşamada, üç faktörün yorumunda Varimax dikey eksen kullanılmıştır. Varimax döndürme esnasında, ölçekten 6 madde .10 faktör yükleri arasındaki her maddenin fark değerini karşılamadığı için silinmiştir (Çokluk, Şekercioğlu ve Büyüköztürk, 2010). Uygun olmayan maddeler silindikten sonra, her üç boyut için ortak varyansın sırasıly \%23.92, $\% 14.67$ ve $\% 15.80$ olduğu görülmüştür. $\% 40$ ve $\% 60$ arasındaki toplam varyans değerinin sosyal bilimlerde yeterli olduğu iddia edilmektedir ve bir faktörün anlamlı olması için açıklanan toplam 
varyansın en az \%5'i o faktöre ilişkin olmalıdır (Çokluk, Şekercioğlu ve Büyüköztürk, 2010; Tavşanc1l, 2002).

Varimax dikey eksen döndürme sonrasında, 3 faktör altında 22 maddeden oluşan ölçek "Ekonomik Destek", "Sosyal Etki” ve “Akademik Katkı” olarak adlandırılmıştır. "Ekonomik Destek” faktörü 5 maddeden oluşmaktadır ve bu faktörün madde yükü .416 ile .801 arasındadır. "Sosyal Etki” faktörü 7 maddeden oluşmaktadır ve faktör yükleri .527 ile .828 arasında değişmektedir. Son faktör olan "Akademik Katkı" ise 9 maddeden oluşmaktadır ve maddelerin faktör yükleri 443 ile .696 arasındadır. Son olarak, ölçeğin güvenirliğini test etmek amacıyla diğer bir deyişle ölçeğin iç tutarlılığını anlayabilmek için, uygulanan güvenirlik hesaplaması sonucunda güvenirlik katsayısı olarak Alpha $=.90$ olarak bulunmuştur. Cronbach-Alpha güvenilirlik katsayısı, ölçeğin test puanları arasındaki iç tutarlılığının bir ölçüsüdür. Bu değerin .70 ve üzeri değerde olması test güvenilirliği için yeterli kabul edilmektedir (Büyüköztürk, 2012). Ölçeğin iç tutarlılığı için Cronbach-Alpha katsayıları alt boyutlara göre de hesaplanmış ve sonuçlar Tablo 2'de verilmiştir.

Tablo 2.

Destekleme ve Yetiştirme Kurslarına Yönelik Tutum Ölçeği Faktör Analizi Sonuçları

\begin{tabular}{|c|c|c|c|c|}
\hline Faktör Adı & $\begin{array}{c}\text { Madde } \\
\text { Numarası }\end{array}$ & $\begin{array}{c}\text { Faktör Yük } \\
\text { Değeri }\end{array}$ & $\begin{array}{c}\text { Faktörün } \\
\text { Açıklayıcılığı } \\
(\%)\end{array}$ & $\begin{array}{c}\text { Güvenirlik } \\
\text { Katsayısı } \\
\text { (Cronbach's } \\
\text { Alpha) } \\
\end{array}$ \\
\hline \multirow{5}{*}{ Ekonomik Destek } & 1 & .692 & \multirow{5}{*}{23,92} & \multirow{5}{*}{.80} \\
\hline & 2 & .672 & & \\
\hline & 3 & .416 & & \\
\hline & 4 & .801 & & \\
\hline & 7 & .782 & & \\
\hline \multirow{7}{*}{ Sosyal Etki } & 10 & .527 & \multirow{7}{*}{14.67} & \multirow{7}{*}{.76} \\
\hline & 15 & .646 & & \\
\hline & 16 & .791 & & \\
\hline & 17 & .828 & & \\
\hline & 18 & .823 & & \\
\hline & 19 & .562 & & \\
\hline & 20 & .528 & & \\
\hline \multirow{9}{*}{ Akademik Katkı } & 9 & .443 & \multirow{9}{*}{15.80} & \multirow{9}{*}{.80} \\
\hline & 12 & .653 & & \\
\hline & 13 & .618 & & \\
\hline & 22 & .669 & & \\
\hline & 23 & .559 & & \\
\hline & 24 & .687 & & \\
\hline & 26 & .617 & & \\
\hline & 27 & .696 & & \\
\hline & 28 & .662 & & \\
\hline \multicolumn{5}{|c|}{$\begin{array}{l}\text { Açıklanan Toplam Varyans }=54.39 \\
\text { Kaiser Meyer Olkin }(K M O)=.876 \\
\text { Barlett Sphericity Testi Ki Kare }=3319.334 \\
s d=231 \\
p=.000 \\
\text { Toplam Cronbach's Alpha }=.90\end{array}$} \\
\hline
\end{tabular}


AFA'da elde edilen üç faktörlü modelin verilerle uyum sağlayıp sağlamadığını test etmek için doğrulayıcı faktör analizi (DFA) kullanılmıştır. Bu yüzden, AFA'da kullanılan 435 durum için veri seti AMOS istatistik programına yüklenmiştir. Doğrulayıcı faktör analizi sonucunda, normalliğin değerlendirilmesi dikkate alındığında, multivariate (Mardia) değerleri açısından kritik oranın (c.r.) 45.40 olduğu ortaya çıkmıştır. Kritik oranı 10'dan büyük maddeler olmadığ 1 için sonraki adımda tüm maddeler analize dâhil edilmiştir. Bu durumda 22 maddeden oluşan "Destekleme ve Yetiştirme Kurslarına Yönelik Tutum Ölçeğinin doğrulayıcı faktör analizinde MI (Modification Indices) değerleri dikkate alınarak yapılan analiz sonucunda uyum değerleri RMSEA=.061; SRMR=.089; $\chi 2 / \mathrm{sd}$ $(\mathrm{CMIN} / \mathrm{DF})=2.62 ; \mathrm{GFI}=.911 ; \mathrm{CFI}=.901 ; \mathrm{AGFI}=.875$ ve NFI=.896 şeklinde ortaya çı1kmıştır. Sınanan modelin yeterliğini ortaya koymak amacıyla incelenen uyum indekslerine ilişkin kabul edilebilir ve mükemmel uyum değerleri ile DFA'dan elde edilen uyum indeksi değerleri ve bu doğrultuda ortaya çıkan sonuçlar Şekil 1'de gösterilmiştir. Şekil 1'deki uyum indekslerine ilişkin mükemmel ve kabul edilebilir uyum ölçütleri, DFA'dan elde edilen dört faktörlü modelin uyum düzeyinin yeterli olduğunu ortaya koymaktadır. 


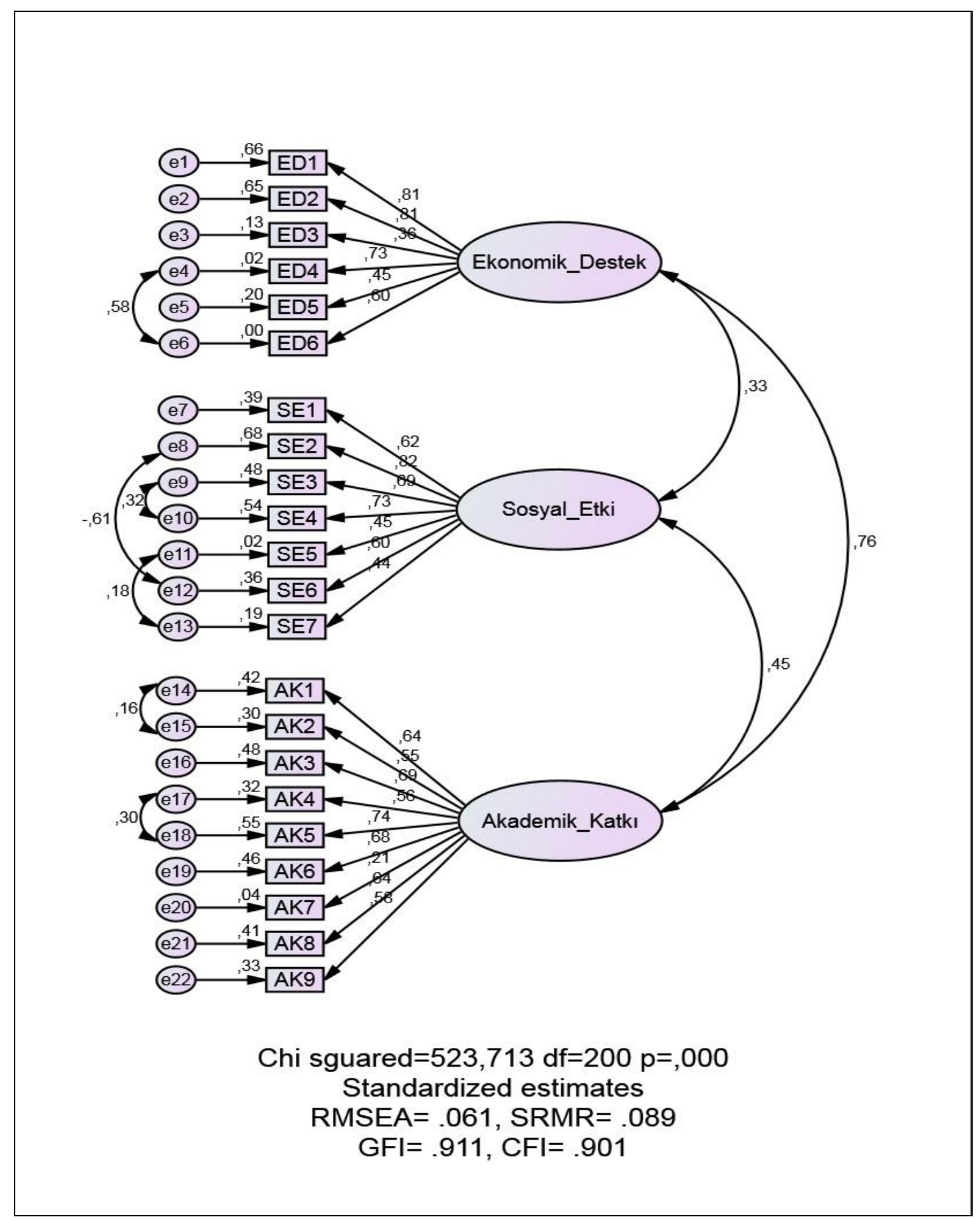

Şekil 1. Destekleme ve Yetiştirme Kurslarına Yönelik Tutum Ölçeği’nin Doğrulayıcı Faktör Analizi Diyagramı

Verilerin Analizi

Çalışmadan elde edilen veriler SPSS ve AMOS paket programları aracılığı ile analiz edilmiştir. Öğretmenlerin destekleme ve yetiştirme kurslarına ilişkin görüşlerini ortaya koymak için uygulanan ölçekten elde edilen verilerin analizinde kullanılacak istatistiksel yöntemleri belirlemek amacıyla, normal dağılıma uygunluk analizinde Kolmogrov-Smirnov Z sinaması, verilerin homojenlik 
durumunu tespit etmek için de Levene sınaması kullanılmıştır. Bu sınamaların sonuçlarına göre, cinsiyet değişkeninde bağımsız örneklemler için t test; yaş ve branş değişkenlerinde Tek Faktörlü Varyans Analizi (One-Way ANOVA); mesleki kıdem değişkeninde ise Kruskal Wallis-H testi kullanılmıştır. Bu testler sonucunda anlamlı farklılığın hangi denek grupları arasında gerçekleştiğini belirleyebilmek için Least Significant Difference (LSD) ve Mann-Whitney U testleri ile çoklu karşılaştırmalar yapılmıştır.

Ayrıca, ölçeğin doğrulayıcı faktör analizinde model parametrelerinin tahmin edilmesinde maksimum olabilirlik tahmin yöntemi kullanılmıştır. Uyum iyiliğinin değerlendirilmesinde; RMSEA (yaklaşık hataların ortalama karekökü), SRMR (standardize edilmiş kalıntıların ortalama karekökü), GFI (uyum iyiliŭi indeksi), CFI (karşılaştırmalı uyum indeksi), AGFI (düzeltilmiş uyum iyiliği indeksi), NFI (normlandırılmış uyum indeksi), $\chi 2 / \mathrm{sd}=\mathrm{CMIN} / \mathrm{DF}$ (ki-kare/serbestlik derecesi) ve anlamlılık düzeyi (p) uyum indeksleri dikkate alınmıştır. Denek yanıtları da boyutlar çerçevesinde, aritmetik ortalama değerlerine göre, $\bar{x} \leq 1.80$ Kesinlikle Katılmıyorum; $1.81 \leq \bar{x} \leq 2.60$ Katılmıyorum; $2.61 \leq \bar{x} \leq 3.40$ Kararsızım; $3.41 \leq \bar{x} \leq 4.20$ Kat1liyorum ve $\bar{x} \geq 4.21$ Kesinlikle Katıllyorum şeklinde düzeyler oluşturulmak suretiyle seçeneklere verilen yanıtlar değerlendirilmiştir.

\section{BULGULAR}

Çalışmada, öğretmenlerin araştırma konusuna ilişkin genel tutumları ile demografik nitelikleri çerçevesinde şekillenen cinsiyet, yaş, mesleki kıdem ve branş değişkenleri bakımından tutumlarına ilişkin elde edilen bulgular aşağıda yorumlanmıştır.

\section{Öğretmenlerin Boyutlar Temelinde Genel Tutumlarına Göre Bulgular ve Yorumu}

Ortaokullarda görev yapan öğretmenlerin destekleme ve yetiştirme kurslarına ilişkin tutumlarına ait betimsel istatistikler incelendiğinde, öğretmenlerin destekleme ve yetiştirme kurslarının öğrenci, veli ve öğretmenlere sağladığ1 ekonomik desteğe yönelik tutumlarının ( $\bar{x}=3.77)$ üst düzeyde olduğu; öğrencilerin, öğretmenlerin ve ailelerinin sosyal yaşamına olan etkilerine yönelik tutumlarının $(\bar{x}=3.11)$ orta düzeyde, öğrencilere ve öğretmenlere olan akademik katkısına yönelik tutumlarının ise $(\bar{x}=4.25)$ çok üst düzeyde olduğu görülmektedir. Ayrıca, öğretmenlerin DYK’ya yönelik genel tutumlarının da üst düzeyde ( $\bar{x}=3.82)$ olduğu bulgusuna ulaşılmıştır (Tablo 3 ).

Tablo 3

Öğretmenlerin Boyutlar Temelinde Genel Görüşlerine Göre Betimsel İstatistikler

\begin{tabular}{lccccc}
\hline Boyutlar & $\mathrm{N}$ & $\overline{\mathrm{X}}$ & $\mathrm{SS}$ & $\mathrm{SH}$ & Yorum \\
\hline Ekonomik Destek & 435 & 3.77 & .52 & .02 & Üst düzey \\
Sosyal Etki & 435 & 3.31 & .74 & .04 & Orta düzey \\
Akademik Katkl & 435 & 4.25 & .52 & .03 & Çok üst düzey \\
Genel Tutum & 435 & 3.82 & .48 & .02 & Üst düzey \\
\hline
\end{tabular}


Dolayısıyla, öğretmenlerin destekleme ve yetiştirme kurslarına yönelik tutumlarının en yüksek düzeyde olduğu boyutun, bu kursların akademik yönden hem öğrencilere hem de öğretmenlere sağladığ1 katkılar yönünde olduğu görülmektedir. Buna karş1lık, kurslara katılımın özel bir zaman ayırmayı gerektirmesinin ortaya çıkardığı sosyal yaşama olan etkileri boyutunun en düşük düzeydeki tutumları yansıttığı da görülmektedir.

\section{Cinsiyet Değişkenine Göre Bulgular ve Yorumu}

Öğretmenlerin destekleme ve yetiştirme kurslarına ilişkin tutumlarının, cinsiyetlerine göre farklılık gösterip göstermediğini belirlemek için yapılan ilişkisiz örneklemler için $\mathrm{t}$ testine göre, ekonomik destek $\left[\mathrm{t}_{(433)}=-.03, \mathrm{p}>0\right]$, sosyal etki $\left[\mathrm{t}_{(433)}=.23, \mathrm{p}>0\right]$ ve akademik katk1 $\left[\mathrm{t}_{(433)}=.66, \mathrm{p}>0\right]$ boyutları ile genel tutumlarında $\left[\mathrm{t}_{(433)}=.41, \mathrm{p}>0\right.$ ] erkek katılımcıların test puan ortalamaları ile kadın katılımcıların test puan ortalamaları arasında anlamlı bir farklılık görülmemiştir ( $p>0.05)$. Bu bulgu, öğretmenlerin DYK'ya ilişkin tutumları ile cinsiyet arasında anlamlı bir ilişkinin olmadığını göstermektedir (Tablo 4).

Tablo 4.

Boyutlar Temelinde Cinsiyet Değişkenine Göre Verilerin Dağılımı

\begin{tabular}{|c|c|c|c|c|c|c|c|c|}
\hline Boyutlar & Gruplar & $\mathrm{N}$ & $\bar{X}$ & $S$ & sd & $\mathrm{t}$ & $\mathrm{P}$ & $\begin{array}{c}\text { Eta Kare } \\
\left(\eta^{2}\right)\end{array}$ \\
\hline \multirow{3}{*}{ Ekonomik Destek } & A) Kadın & 169 & 3.77 & .45 & & & & - \\
\hline & B) Erkek & 266 & 3.77 & .56 & 433 & -.03 & .97 & \\
\hline & Toplam & 435 & & & & & & \\
\hline \multirow{3}{*}{ Sosyal Etki } & A) Kadın & 169 & 3.32 & .70 & & & & - \\
\hline & B) Erkek & 266 & 3.31 & .77 & 433 & .23 & .82 & \\
\hline & Toplam & 435 & & & & & & \\
\hline \multirow{3}{*}{ Akademik Katk1 } & A) Kadın & 169 & 4.27 & .52 & & & & \\
\hline & B) Erkek & 266 & 4.24 & .53 & 433 & .66 & .51 & - \\
\hline & Toplam & 435 & & & & & & \\
\hline \multirow{3}{*}{ Genel Tutum } & A) Kadın & 169 & 3.83 & .44 & & & & \\
\hline & B) Erkek & 266 & 3.81 & .50 & 433 & .41 & .69 & - \\
\hline & Toplam & 435 & & & & & & \\
\hline
\end{tabular}

Yaş Değişkenine Göre Bulgular ve Yorumu

Araştırmaya katılan öğretmenlerin destekleme ve yetiştirme kurslarına ilişkin tutumlarının yaş değişkenine göre anlamlı bir farklılık gösterip göstermediğini belirlemek amacıyla yapılan tek yönlü varyans analizi (One-Way ANOVA) sonucunda; ekonomik destek $\left[\mathrm{F}_{(2-434)}=.30, \mathrm{p}>0.05\right]$, sosyal etki $\left[\mathrm{F}_{(2-434)}=.81, \mathrm{p}>0.05\right]$, akademik katk1 $\left[\mathrm{F}_{(2-434)}=.43, \mathrm{p}>0.05\right]$ boyutlarında ve genel tutumlarında $\left[\mathrm{F}_{(2-}\right.$ $\left.{ }_{434)}=.14, \mathrm{p}>0.05\right]$ katılımcıların yaşları bakımından istatistiksel olarak anlamlı bir farkın olmadığı görülmüştür. Başka bir deyişle, öğretmenlerin DYK'ya ilişkin tutumları, yaşlarına bağlı olarak anlamlı bir şekilde farklılaşmamaktadır (Tablo 5). 
Tablo 5

Boyutlar Temelinde Yaş Değişkenine Göre Verilerin Dağılımı

\begin{tabular}{|c|c|c|c|c|c|c|c|c|c|c|}
\hline Boyutlar & Gruplar & $\mathrm{N}$ & $\mathrm{X}$ & $\begin{array}{c}\text { Varyansın } \\
\text { Kaynağ1 }\end{array}$ & $\begin{array}{c}\text { Kareler } \\
\text { Toplamı }\end{array}$ & $\mathrm{Sd}$ & $\begin{array}{c}\text { Kareler } \\
\text { Ortalamas1 } \\
\end{array}$ & $\mathrm{F}$ & $\mathrm{p}$ & $\begin{array}{c}\text { Anlamlı } \\
\text { fark } \\
\text { (LSD) }\end{array}$ \\
\hline \multirow{4}{*}{$\begin{array}{l}\text { Ekonomik } \\
\text { Destek }\end{array}$} & A) 30 yaş ve altı & 140 & 3.78 & Gruplar & 150 & 2 & 08 & \multirow{4}{*}{.30} & \multirow{4}{*}{.74} & \multirow{4}{*}{-} \\
\hline & B) $31-40$ yaş & 212 & 3.77 & aras1 & 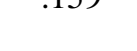 & 2 & .00 & & & \\
\hline & C) 41 yaş ve üzeri & 83 & 3.73 & \multirow[t]{2}{*}{$\begin{array}{l}\text { Gruplar } \\
\text { içi }\end{array}$} & 116.135 & 432 & .70 & & & \\
\hline & Toplam & 435 & 3.77 & & 116.294 & 434 & & & & \\
\hline \multirow{4}{*}{ Sosyal Etki } & A) 30 yaş ve altı & 140 & 3.28 & \multirow{2}{*}{$\begin{array}{l}\text { Gruplar } \\
\text { aras1 }\end{array}$} & \multirow{2}{*}{.893} & \multirow{2}{*}{2} & \multirow{2}{*}{.45} & \multirow{4}{*}{.81} & \multirow{4}{*}{.44} & \multirow{4}{*}{-} \\
\hline & B) $31-40$ yaş & 212 & 3.36 & & & & & & & \\
\hline & C) 41 yaş ve üzeri & 83 & 3.25 & \multirow[t]{2}{*}{$\begin{array}{l}\text { Gruplar } \\
\text { içi }\end{array}$} & 237.623 & 432 & .55 & & & \\
\hline & Toplam & 435 & 3.31 & & 238.516 & 434 & & & & \\
\hline \multirow{4}{*}{$\begin{array}{l}\text { Akademik } \\
\text { Katk1 }\end{array}$} & A) 30 yaş ve altı & 140 & 4.28 & \multirow{2}{*}{$\begin{array}{l}\text { Gruplar } \\
\text { aras1 }\end{array}$} & \multirow{2}{*}{.236} & \multirow{2}{*}{2} & \multirow{2}{*}{.12} & \multirow{4}{*}{.43} & \multirow{4}{*}{.65} & \multirow{4}{*}{ - } \\
\hline & B) $31-40$ yaş & 212 & 4.23 & & & & & & & \\
\hline & C) 41 yaş ve üzeri & 83 & 4.26 & \multirow[t]{2}{*}{$\begin{array}{l}\text { Gruplar } \\
\text { içi }\end{array}$} & 118.845 & 432 & .28 & & & \\
\hline & Toplam & 435 & 4.25 & & 119.081 & 434 & & & & \\
\hline \multirow{4}{*}{ Genel Tutum } & A) 30 yaş ve altı & 140 & 3.83 & \multirow{2}{*}{$\begin{array}{l}\text { Gruplar } \\
\text { aras1 }\end{array}$} & \multirow{2}{*}{.066} & \multirow{2}{*}{2} & \multirow{2}{*}{.03} & \multirow{4}{*}{.14} & \multirow{4}{*}{.87} & \multirow{4}{*}{-} \\
\hline & B) $31-40$ yaş & 212 & 3.83 & & & & & & & \\
\hline & C) 41 yaş ve üzeri & 83 & 3.80 & \multirow[t]{2}{*}{$\begin{array}{l}\text { Gruplar } \\
\text { içi }\end{array}$} & 98.358 & 432 & \multirow[t]{2}{*}{.23} & & & \\
\hline & Toplam & 435 & 3.82 & & 98.423 & 434 & & & & \\
\hline
\end{tabular}

\section{Mesleki Kıdem Değişkenine Göre Bulgular ve Yorumu}

Farklı üç mesleki kıdeme göre gruplandırılmış öğretmenlerin, destekleme ve yetiştirme kurslarına ilişkin tutumlarına yönelik Kruskal-Wallis H testi sonuçları Tablo 6'da verilmiştir. Analiz sonuçları, araştırmaya katılan öğretmenlerin DYK'ya ilişkin tutumlarının ekonomik destek $\left[\chi_{(2)}^{2}=.089\right.$, $\mathrm{p}>0.05]$, sosyal etki $\left[\chi_{(2)}^{2}=4.281, \mathrm{p}>0.05\right]$, akademik katk1 $\left[\chi^{2}(2)=1.550, \mathrm{p}>0.05\right]$ boyutlarında ve DYK'ya yönelik genel tutumlarında $\left[\chi_{(2)}^{2}=2.038, \mathrm{p}>0.05\right]$ farklılaşmadığını göstermektedir. Bu bulgu, öğretmenlerin DYK'ya ilişkin tutumlarında mesleki kıdem değişkeninin etkili olmadığını göstermektedir (Tablo 6). 
Tablo 6

Boyutlar Temelinde Mesleki Kıdem Değişkenine Göre Verilerin Dağılımı

\begin{tabular}{|c|c|c|c|c|c|c|c|}
\hline Boyutlar & Gruplar & $\mathrm{N}$ & $\begin{array}{c}\text { Sira } \\
\text { Ortalaması }\end{array}$ & sd & $\chi^{2}$ & $\mathrm{P}$ & $\begin{array}{c}\text { Anlamlı fark } \\
\text { (Mann } \\
\text { Whitney U) }\end{array}$ \\
\hline \multirow{4}{*}{ Ekonomik Destek } & A) 10 yıl ve daha az & 204 & 217.61 & \multirow{4}{*}{2} & \multirow{4}{*}{.089} & \multirow{4}{*}{.96} & \multirow{4}{*}{-} \\
\hline & B) $11-20 \mathrm{y} 1 \mathrm{l}$ & 180 & 217.07 & & & & \\
\hline & C) 21 y1l ve üzeri & 51 & 222.85 & & & & \\
\hline & Toplam & 435 & & & & & \\
\hline \multirow{4}{*}{ Sosyal Etki } & A) 10 yıl ve daha az & 204 & 205.01 & \multirow{4}{*}{2} & \multirow{4}{*}{4.281} & \multirow{4}{*}{.12} & \multirow{4}{*}{-} \\
\hline & B) $11-20 \mathrm{y} 1 \mathrm{l}$ & 180 & 231.24 & & & & \\
\hline & C) 21 y1l ve üzeri & 51 & 223.24 & & & & \\
\hline & Toplam & 435 & & & & & \\
\hline \multirow{4}{*}{ Akademik Katkı } & A) 10 yil ve daha az & 204 & 211.42 & \multirow{4}{*}{2} & \multirow{4}{*}{1.550} & \multirow{4}{*}{.46} & \multirow{4}{*}{-} \\
\hline & B) $11-20 \mathrm{y} 1 \mathrm{l}$ & 180 & 220.74 & & & & \\
\hline & C) 21 y1l ve üzeri & 51 & 234.66 & & & & \\
\hline & Toplam & 435 & & & & & \\
\hline \multirow{4}{*}{ Genel Tutum } & A) 10 yil ve daha az & 204 & 209.07. & \multirow{4}{*}{2} & \multirow{4}{*}{2.038} & \multirow{4}{*}{.36} & \multirow{4}{*}{-} \\
\hline & B) $11-20$ y1l & 180 & 224.51 & & & & \\
\hline & C) 21 y1l ve üzeri & 51 & 230.74 & & & & \\
\hline & Toplam & 435 & & & & & \\
\hline
\end{tabular}

$* \mathrm{p}<0.05$

\section{Branş Değişkenine Göre Bulgular ve Yorumu}

Öğretmenlerin destekleme ve yetiştirme kurslarına ilişkin tutumlarının branş değişkenine göre anlamlı bir farklılık gösterip göstermediğini belirlemek amacıyla yapılan tek yönlü varyans analizi (One-Way ANOVA) sonucunda; akademik katkı boyutunda öğretmen tutumları arasında istatistiksel olarak anlamlı bir fark görülmüştür $\left[\mathrm{F}_{(6-434)}=3.27, \mathrm{p}<0.05\right]$. Birimler aras1 farkın hangi gruplar arasında olduğunu bulmak amacıyla yapılan LSD testi sonucunda anlamlı farkın, 'Türkçe, Fen Bilimleri, Sosyal Bilgiler ve Yabancı Dil branşlarındaki öğretmenler ile Diğer (Görsel Sanatlar, Müzik, Beden Eğitimi ve Spor vb.) branşlardaki öğretmenler arasında olduğu görülmüştür $(\mathrm{p}=.00)$. Buna göre, Türkçe $\left(\bar{x}_{A}=4.28\right)$, Fen Bilimleri $\left(\bar{x}_{C}=4.38\right)$, Sosyal Bilgiler $\left(\bar{x}_{D}=4.35\right)$ ve Yabanc1 Dil $\left(\bar{x}_{\mathrm{A}}=4.35\right)$ branşlarındaki öğretmenlerin, Diğer branşındaki $\left(\bar{x}_{\mathrm{G}}=4.04\right)$ öğretmenlere nazaran DYK'nın akademik katkısına ilişkin tutumlarının "daha yüksek" olduğu görülmüştür (Tablo 7). Ancak, ekonomik destek $\left[\mathrm{F}_{(6-434)}=1.18, \mathrm{p}>0.05\right]$ ve sosyal etki $\left[\mathrm{F}_{(6-434)}=.69, \mathrm{p}>0.05\right]$ boyutlar1 ile genel tutumlarında $\left[\mathrm{F}_{(6-434)}=1.78, \mathrm{p}>0.05\right]$ öğretmenlerin DYK'ya ilişkin tutumları arasında branşları bakımından istatistiksel olarak anlamlı bir fark olmadığı görülmektedir (Tablo 7). 
Tablo 7

Boyutlar Temelinde Branş Değişkenine Göre Verilerin Dağılımı

\begin{tabular}{|c|c|c|c|c|c|c|c|c|c|c|}
\hline Boyutlar & Gruplar & $\mathrm{N}$ & $\bar{X}$ & $\begin{array}{c}\text { Varyansın } \\
\text { Kaynağ1 }\end{array}$ & $\begin{array}{c}\text { Kareler } \\
\text { Toplam } 1\end{array}$ & $\mathrm{Sd}$ & $\begin{array}{c}\text { Kareler } \\
\text { Ortalaması }\end{array}$ & $\mathrm{F}$ & $\mathrm{p}$ & $\begin{array}{l}\text { Anlamli } \\
\text { fark } \\
\text { (LSD) }\end{array}$ \\
\hline \multirow{8}{*}{$\begin{array}{l}\text { Ekonomik } \\
\text { Destek }\end{array}$} & A) Türkçe & 85 & 3.81 & \multirow{4}{*}{$\begin{array}{l}\text { Gruplar } \\
\text { aras1 }\end{array}$} & \multirow{4}{*}{1.896} & \multirow{4}{*}{6} & \multirow{4}{*}{.32} & \multirow{8}{*}{1.18} & \multirow{8}{*}{.31} & \multirow{8}{*}{-} \\
\hline & B) Matematik & 84 & 3.80 & & & & & & & \\
\hline & C) Fen Bilimleri & 56 & 3.77 & & & & & & & \\
\hline & D) Sosyal Bilgiler & 54 & 3.85 & & & & & & & \\
\hline & E) Yabancı Dil & 52 & 3.77 & \multirow{4}{*}{$\begin{array}{l}\text { Gruplar } \\
\text { içi }\end{array}$} & \multirow{3}{*}{114.398} & \multirow{3}{*}{428} & \multirow{4}{*}{.27} & & & \\
\hline & F) DKAB & 40 & 3.67 & & & & & & & \\
\hline & G) Diğer & 64 & 3.65 & & & & & & & \\
\hline & Toplam & 435 & 3.77 & & 116.294 & 434 & & & & \\
\hline \multirow{8}{*}{$\begin{array}{l}\text { Sosyal } \\
\text { Etki }\end{array}$} & A) Türkçe & 85 & 3.42 & \multirow{4}{*}{$\begin{array}{l}\text { Gruplar } \\
\text { aras1 }\end{array}$} & \multirow{4}{*}{2.286} & \multirow{4}{*}{6} & \multirow{4}{*}{.38} & \multirow{8}{*}{.69} & \multirow{8}{*}{.66} & \multirow{8}{*}{ - } \\
\hline & B) Matematik & 84 & 3.32 & & & & & & & \\
\hline & C) Fen Bilimleri & 56 & 3.29 & & & & & & & \\
\hline & D) Sosyal Bilgiler & 54 & 3.26 & & & & & & & \\
\hline & E) Yabanc1 Dil & 52 & 3.38 & \multirow{4}{*}{$\begin{array}{l}\text { Gruplar } \\
\text { içi }\end{array}$} & \multirow{3}{*}{236.231} & \multirow{3}{*}{428} & \multirow{4}{*}{.55} & & & \\
\hline & F) DKAB & 40 & 3.24 & & & & & & & \\
\hline & G) Diğer & 64 & 3.21 & & & & & & & \\
\hline & Toplam & 435 & 3.31 & & 238.516 & 434 & & & & \\
\hline \multirow{8}{*}{$\begin{array}{l}\text { Akademik } \\
\text { Katk1 }\end{array}$} & A) Türkçe & 85 & 4.28 & \multirow{4}{*}{$\begin{array}{l}\text { Gruplar } \\
\text { aras1 }\end{array}$} & \multirow{4}{*}{5.223} & & & & & \\
\hline & B) Matematik & 84 & 4.20 & & & 6 & 87 & & & \\
\hline & C) Fen Bilimleri & 56 & 4.38 & & & 0 & . .01 & & & $A$ \\
\hline & D) Sosyal Bilgiler & 54 & 4.35 & & & & & 207 & $\Omega \cap *$ & C-G \\
\hline & E) Yabanc1 Dil & 52 & 4.35 & & & & & 0.21 & $.00^{*}$ & D-G \\
\hline & F) DKAB & 40 & 4.20 & Gruplar & 113.858 & 428 & .27 & & & E-G \\
\hline & G) Diğer & 64 & 4.04 & & & & & & & \\
\hline & Toplam & 435 & 4.25 & & 119.081 & 434 & & & & \\
\hline & A) Türkçe & 85 & 3.88 & & & & & & & \\
\hline & B) Matematik & 84 & 3.81 & Gruplar & 306 & 6 & 40 & & & \\
\hline & C) Fen Bilimleri & 56 & 3.87 & aras1 & 2.390 & 0 & .40 & & & \\
\hline Genel & D) Sosyal Bilgiler & 54 & 3.87 & & & & & 170 & 10 & \\
\hline Tutum & E) Yabanc1 Dil & 52 & 3.88 & & & & & $1 . / 8$ & .10 & - \\
\hline & F) DKAB & 40 & 3.75 & $\begin{array}{l}\text { Gruplar } \\
\text { ici }\end{array}$ & 96.028 & 428 & .22 & & & \\
\hline & G) Diğer & 64 & 3.67 & & & & & & & \\
\hline & Toplam & 435 & 3.82 & & 98.423 & 434 & & & & \\
\hline
\end{tabular}

$* p<.05$ 


\section{TARTIŞMA, SONUÇ VE ÖNERİLER}

Türkiye'de ilk olarak 2014-2015 eğitim-öğretim y1lında uygulamaya konulan destekleme ve yetiştirme kursları oldukça yeni bir uygulamadır. Her yeni uygulamada olduğu gibi bu kurslarda da uygulama sürecinde göze çarpan, uygulayıcılara süreç ile ilgili değerlendirme yapma firsatı tanıyan unsurlar bulunmaktadır. Bu kurslarda görev yapan öğretmenlerin uygulamaya dönük görüşleri, ilk elden sağlıklı ve güvenilir bilgi alma noktasında büyük değere sahiptir. Bu çalışma kapsamında; cinsiyet, yaş, mesleki kıdem ve branş değişkenlerinin resmi devlet ortaokullarında görev yapan öğretmenlerin Destekleme ve Yetiştirme Kurslarına yönelik tutumlarına olan etkisi incelenmeye çalışılmıştır.

Ortaokullarda görev yapan öğretmenlerin destekleme ve yetiştirme kurslarına ilişkin genel tutumlarından elde edilen sonuçlar, bu kursların sağladığı ekonomik desteğe yönelik tutumlarının üst düzeyde; öğrencilerin, öğretmenlerin ve ailelerinin sosyal yaşamına olan etkilerine yönelik tutumlarının orta düzeyde, öğrencilere ve öğretmenlere olan akademik katkısına yönelik tutumlarının ise çok üst düzeyde olduğunu göstermiştir. Ayrıca, öğretmenlerin DYK'ya yönelik genel tutumlarının da üst düzeyde olduğu anlaşılmıştır. Bu sonuçla aynı doğrultuda, Uğurlu (2017)'nun çalışmasında da öğretmenlerin destekleme ve yetiştirme kurslarına ilişkin öz algılarının "Katılıyorum” düzeyinde olduğu belirlenmiştir. Bu durum öğretmenlerin destekleme ve yetiştirme kurslarına yönelik bakış açılarının olumlu olduğu sonucunu ortaya koymaktadır. Bu araştırmada, öğretmenlerin destekleme ve yetiştirme kurslarında dönük öz algılarının en yüksek düzeyde akademik katkı, en düşük düzeyde ise sosyal etki boyutlarında olduğu sonucuna varılmıştır. Başka bir ifadeyle öğretmenlerin, DYK'nın sağladığı ekonomik destek veya yaptığı sosyal etkiden öte akademik katkısına yoğunlaştıkları görülmüştür. Akademik yönden katkının özellikle; kurslara katılan öğrencilerin hafta içi derslerini daha iyi kavradıkları ve eksikliklerini giderme firsatı buldukları, katılımın gönüllülük esasına dayalı olmasının dersleri daha verimli kıldığı, öğrenci başarılarının daha iyi takip edilebildiği, geçirilen zamanın artması ile öğrencileri yakından tanıma fırsatı bulunduğu, öğretmenin alan bilgisini geliştirmesinde ve güncel tutmasında teşvik edici olduğu sonuçlarına ulaşılmıştır. Benzer sonuçların elde edildiği Ünsal ve Korkmaz (2016)'ın çalışmasında da destekleme ve yetiştirme kursunun öğrenciye katkısı bağlamında öğretmenler; öğrencilerin daha çok ders ve sınav başarılarını artırdığını, soru çözme becerilerini geliştirdiği şeklinde görüş belirtmişlerdir. Canpolat ve Köçer (2017)'in çalışmasına katılan Sosyal Bilgiler öğretmenleri kursların bu yönleriyle öğrencilere hem sosyal beceriler kazandırdığını hem de özgüven ve akademik başarı açısından olumlu katkı sağladığını vurgulamaktadır. Nartgün ve Dilekçi (2016)'nin araştırmasına katılan 8. sınıf öğrencilerinin \%98.44'ünün destekleme ve yetiştirme kurslarının ders performanslarını artırdığını ifade etmiştir. Benzer şekilde Metsäpelto ve Pulkkinen (2012), Akın (2012), Massoni (2011), Shernoff (2010), 
Lauver (2002), Hock ve diğerleri (2001), Miranda (2001), Holloway (1999) ve Mahoney ve Cairns (1997) yaptıkları çalışmalar da bu bulguyu destekler niteliktedir. Alan yazınında bazı çalışmalarda ise, öğretmen görüşlerinin daha çok kursların ekonomik desteğine yoğunlaştığ1 görülmektedir. Demir Başaran ve Narinalp Yıldız (2017)'ın çalışmasına katılan öğretmenler, kurslarda verdikleri dersler sayesinde gelirlerinde meydana gelen artışın kursların kendileri için en önemli yararlarından biri olduğunu belirtmişlerdir. Öğretmenler bu kursların mesleki gelişimlerine de katkıda bulunduğunu, hafta içi tamamlayamadıkları derslere ait telafi yapabildiklerini, kendi hizmet puanlarına katkı sağladığını, daha özgür bir ortamda ders verdiklerini, öğrencilere firsat eşitliği sağladığını ve öğrencilerin akademik başarılarını artırdığını belirtmişlerdir. $\mathrm{Bu}$ sonuçlar, kurslara yönelik araştırmasında kursun en önemli yararları olarak gelir ve puan artışı sonucuna ulaşan Ünsal ve Korkmaz (2016) tarafindan desteklenmektedir. Ünsal ve Korkmaz (2016)'ın çalışmasında da kursların öğretmene yönelik katkılarının daha çok ekonomik boyutta olduğu ifade edilmektedir. Diğer taraftan ek hizmet puanı uygulaması ise diğer bir katkı olarak öğretmenler tarafından ifade edilmiştir. Dershanelerin kapatılması sürecinden sonra yaygınlaşan destekleme ve yetiştirme kurslarında görev alan öğretmenler girdikleri derslerde normal ek ders ücreti karşılığında çalışmaktaydılar. Milli Eğitim Bakanlığ 1 destekleme ve yetiştirme kursunda öğretmenlerin performansını ve motivasyonunu artırmak adına yapmış olduğu; 15/04/2015 tarih ve 29327 sayı1ı Resmi Gazetede yayımlanan Bazı Kanun ve Kanun Hükmünde Kararnamelerde Değişiklik Yapılması Hakkında Kanunun 9. maddesi ile; 657 sayılı Devlet Memurları Kanununda değişiklik yapılarak "Örgün ve Yaygın Eğitimi Destekleme ve Yetiştirme Kursları Yönergesi kapsamında görev alan yönetici ve öğretmenlere ek ders \%100 fazlasıyla ödenir" şeklinde değişiklik ile "Milli Eğitim Bakanlığı Örgün ve Yaygın Eğitimi Destekleme ve Yetiştirme Kursları Yönergesi kapsamında görev alan yönetici ve öğretmenlerin hizmet puanlarına, bu kapsamda görev yaptıkları her ay için 0,5 puan eklenir” değişikliğinin öğretmenler tarafindan olumlu karşılandığı söylenebilir. Bu değişikliğin hem kursları öğretmenlerin çalışması açısından daha cazip hale getirdiği hem de çalışan mevcut öğretmenleri daha çok motive ettiği söylenebilir. Göksu ve Gülcü (2016)'nün çalışmasında da kurslarda görev almanın en önemli sebebinin ek ders ücreti olduğu sonucu ortaya çıkmıştır. Benzer şekilde Ergün (2017)'ün çalışmasında da Destekleme ve Yetiştirme Kurslarının ekonomi boyutunun öğretmen ve yönetici görüşleri açısından incelenmesi sonucunda, öğretmen ve yöneticilerin genel olarak olumlu görüşler belirttikleri ortaya çıkmıştır. Öğretmenlerin büyük çoğunluğu kurslara ek gelir sebebi ile katıldıklarını, öğretmen ve yöneticilere ödenen ücretlerin yeterli sayılabileceğini gösteren yantlar vermişlerdir. Ancak katılımcılar genel olarak kursların ücretsiz olması ile ilgili olarak ise kursların değerinin azaldığına inanmaktadırlar. Gerçekleştirilen analizler sonucunda katılımcılar öğretmen ve yöneticilere ödenen ücretlerin yeterli sayılabileceğini gösteren yanıtlar vermişlerdir. 
Öğretmenlerin destekleme ve yetiştirme kurslarına yönelik tutumlarının en yüksek düzeyde olduğu boyutun, bu kursların akademik yönden hem öğrencilere hem de öğretmenlere sağladığ katkılar yönünde olmasına karşı1ık, kurslara katılımın özel bir zaman ayırmayı gerektirmesinin ortaya çıkardığı sosyal yaşama olan etkileri boyutunun en düşük düzeydeki tutumları yansıttığı da görülmektedir. Sosyal etkiye yönelik; "kursların hafta sonu olmasının öğrencileri sosyal çevrelerinden uzaklaştırdığı, velilerin öğrencilerle yeterince vakit geçirememesinin öğrencileri kurslardan soğuttuğu, ögrrencilerin hafta sonu da okula gelmeyi gereksiz gördüğü, öğretmenlerin sosyal etkinliklere katılımını olumsuz etkilediği, kendisine ve ailesine yeterince zaman ayıramamasına yol açtığı, kurs yoğunluğunun mesleki bıkkınlığa yol açtığı" ifadelerine öğretmenlerin en düşük düzeyde katılım göstermiş olması, kursların akademik katkılarının neden daha çok olduğuna yönelik tutumlarını açıklar niteliktedir. Alan yazında bazı çalışmalarda ise, sosyal etki kaynaklı olumsuzlukların ön plana çıktığı görülmektedir. Göksu ve Gülcü (2016)'nün çalışmasında kursta görev almayan öğretmenler, sebep olarak ders yoğunluğunu ve aileyle vakit geçirememeyi ileri sürmüşlerdir. Nartgün ve Dilekçi (2016)'nin çalışmasında da öğretmenlerin tümü eğitimi destekleme ve yetiştirme kurslarına yönelik olarak dezavantaj var yönünde görüş belirtmiştir. Destekleme ve yetiştirme kurslarının eksik yönlerine yönelik olarak öğretmenlerce en sık ifade edilen görüşler arasında, kursların yoğun olması ve dolayısıyla bu durumun yorgunluğa sebebiyet vermesi göze çarpmaktadır. Millı̂ Eğitim Bakanlığınca hazırlanan haftalık ders çizelgesine göre ortaokullarda 29 ders saati zorunlu, 6 ders saati seçmeli olmak üzere 35 ders saati işlenmektedir. Bu ders saatlerine ek olarak destekleme ve yetiştirme kurslarında da belli bir oranda ders işlendiği düşünülürse öğrencilerde ve bu dersleri vermekle görevli öğretmenlerde birtakım fiziksel ve zihinsel yorgunluğun ortaya çıkması muhtemeldir. Aynı şekilde Ünsal ve Korkmaz (2016)'ın çalışması da bu durumu destekler niteliktedir, araştırmaya katılan öğretmenler destekleme ve yetiştirme kursunun olumsuzluğuna ilişkin olarak kursların kendilerinde performans düşüklüğüne ve yorgunluğa sebep olduğunu belirtmişlerdir.

Araştırmada elde edilen bir diğer sonuç, öğretmenlerin destekleme ve yetiştirme kurslarına ilişkin tutumları ile cinsiyetleri arasında anlamlı bir ilişkinin olmadığını göstermiştir. Ancak cinsiyet değişkenine göre kadın öğretmenlerin, destekleme ve yetiştirme kurslarının sosyal etkileri ve akademik katkılarına yönelik tutumları ile genel tutumlarının erkek öğretmenlere göre az da olsa daha yüksek düzeyde olduğu tespit edilmiştir. Bu durum, kadın öğretmenlerin toplumdaki annelik rolleri gereği hafta sonunu da okulda geçirmenin kendileri, aileleri ve öğrenciler üzerinde oluşturabileceği etkilerine yönelik tutumları ile akademik yönden de öğretmenlik mesleğine yükledikleri misyonla açıklanabilir. Benzer şekilde Uğurlu (2017)'nun çalışmasında da destekleme ve yetiştirme kurslarına dönük öz algı düzeyleri ile öğretmenlerin cinsiyetleri arasında istatistiksel olarak herhangi bir anlamlı farklılaşma belirlenememiştir. Bu bulgu, araştırma sonuçlarını destekler niteliktedir. 
Araştırmaya katılan öğretmenlerin destekleme ve yetiştirme kurslarına ilişkin tutumları yaşlarına bağlı olarak anlamlı bir şekilde farklılaşmamaktadır. Ancak dikkat çekici bir şekilde, öğretmenlerin yaşları ilerledikçe yani yaşı daha çok olan öğretmenlerin destekleme ve yetiştirme kurslarına yönelik tutumlarının diğer yaş grubunda olan öğretmenlere nazaran az da olsa daha düşük olduğu görülmüştür. Böylesi bir sonucun ortaya çıkmasını tetikleyen sebeplerin başında yaşla birlikte meslekte geçirilen sürenin fazlalaşması öğretmenlerde bir mesleki yorgunluğa yol açtığı düşünülebileceği gibi (hafta içi okula giden öğretmenlerin hafta sonunu da okulda geçirmeyi göze alamamaları vb.), diğer taraftan kazanılan deneyimlerle hafta sonu kurslarda geçirilen sürede öğrencilere öğretilebileceklerin hafta içinde de öğretilebileceğini düşündükleri şeklinde açıklanabilir. Benzer şekilde Uğurlu (2017)'nun çalışmasında öğretmenlerin yaş değişkenine göre destekleme ve yetiştirme kurslarına dönük öz algı düzeyleri incelendiğinde sosyal olumsuzluk, akademik katk1, olumsuz öğrenci ve bireysel katkı boyutlarında anlamlı bir farklılık göstermediği belirlenmiştir.

Araştırmada elde edilen başka bir sonuca göre, öğretmenlerin DYK'ya ilişkin tutumlarının mesleki kıdemlerine göre ekonomik destek, sosyal etki, akademik katkı boyutlarında ve genel anlamda farklılaşmadığı görülmüştür. Bu bulgu, öğretmenlerin DYK'ya ilişkin tutumlarında meslekî kıdem değişkeninin etkili olmadığını göstermiştir. Uğurlu (2017)'nun çalışmasında ise, meslekî kıdem değişkenine göre öz alg1 düzeyleri en yüksek olan grubun 1-5 yıl arası kıdeme sahip olan öğretmenler, en düşük grubun ise 21 yıl ve üzeri kıdeme sahip öğretmenler olduğu belirlenmiştir. Bununla birlikte araştırmaya katılan öğretmenlerin destekleme ve yetiştirme kurslarına dönük öz alg1 düzeylerinin meslekî kıdem değişkenine göre anlamlı bir farklılık göstermediği tespit edilmiştir.

Son olarak, öğretmenlerin destekleme ve yetiştirme kurslarına ilişkin tutumları branş değişkenine göre, akademik katkı boyutunda anlamlı fark görülmüştür. Bu anlamlı fark, "Türkçe, Matematik, Fen Bilimleri, Sosyal Bilgiler ve Yabancı Dil" branşlarındaki öğretmenler ile "Diğer (Görsel Sanatlar, Müzik, Beden Eğitimi ve Spor vb.)" branşlardaki öğretmenler arasında görülmüştür. Türkçe, Matematik, Fen Bilimleri, Sosyal Bilgiler ve Yabancı Dil branşlarındaki öğretmenlerin, Diğer branşındaki öğretmenlere nazaran DYK'nın akademik katkısına ilişkin tutumlarının "daha yüksek" olduğu görülmüştür. $\mathrm{Bu}$ durum, söz konusu branşlardaki öğretmenlerin daha fazla kurs açabilmelerinden, sınav başarısı nedeniyle öğrencilerin bu dersleri daha çok talep etmelerinden kaynaklanıyor olabilir. DYK'ya öğrenciler, Eğitim Bilişim Ağı (EBA) modülü üzerinden istediği dersleri ve bu derslere girmesini istedikleri öğretmenleri seçerek başvuru yapmaktadır. Diğer branşındaki dersler okullara öğrenci seçmeye yönelik merkezi sınavlarda sorulmadığı için fazla talep görmemekte, öğrenciler bu dersleri tercih etmedikleri için bu branşın öğretmenleri kurs açamamaktadır. Benzer şekilde Biber, Tuna, Polat, Altunok ve Küçükoğlu (2017) destekleme ve yetiştirme kurslarıyla ilgili katılımcı öğrencilerin görüşlerini ortaya koyduğu çalışmasında öğrencilerin kurs almak istediği dersler sorulduğunda en çok tercih edilen kursun Matematik, Türkçe ve İngilizce 
dersleri olduğu görülmüştür. Milli Eğitim Bakanlığı'nın açıkladığı verilere göre de geçtiğimiz yıllarda açılması talep edilen kurs sayısının en fazla Matematik dersinde olmuştur. Bunun sebebi olarak öğrencilerin matematik sorularını çözmede sıkıntı yaşadıkları, matematik dersinin sınav başarısında ağırlıklı puan olarak fazla olması ve öğrencilerin bu problemi aşmak için kurs almak istemeleri söylenebilir. Pisa çalışması anket sonuçlarına baktığımızda da ankete katılan 57 ülkeden 42'sinde matematik için özel ders alma oranının \%40’ın üzerinde olduğunu görebiliriz (Lee, Park \& Lee, 2009).

Elde edilen bu sonuçlardan yola çıkarak aşağıdaki önerilere yer verilebilir:

Öğretmenlerin hafta içi ve hafta sonu kurslarda görev almaları yorgunluğa, performans düşüklüğüne ve sosyal hayata yeterince zaman ayıramamalarına sebep olmaktadır. Bu açıdan kursta görev alan öğretmenlerin hafta içi çalışma saatlerine yönelik olarak bir esneklik sağlanarak en azından haftada bir gün dinlenmelerine yönelik düzenleme yapılabilir. Bu şekildeki bir uygulama öğretmenlerin verimliliği ve performansı açısından yararlı olabilir.

Destekleme ve Yetiştirme Kurslarının sadece sınava yönelik Matematik, Türkçe, Fen Bilimleri vb. dersleri için değil, spor, sanat, müzik, drama vb. alanlarda da daha fazla açılması teşvik edilebilir. Farklı ülkelerdeki benzer uygulamalar araştırılabilir. Diğer ülkelerde bulunan okullarda açılan okul sonrası kurslar ile Türkiye'deki destekleme ve yetiştirme kurslarının benzerlik ve farklılıkları hakkında araştırma yapılabilir. Bu çalışma ortaokullarda görev yapan öğretmenlere yönelik olarak yapılmıştır, farklı kademelerde görev alan öğretmenlere yönelik çalışmalar da yapılabilir. Elde edilen sonuçlardan yola çıkarak farklı kademelerde açılmış kursların işlevleri karşılaştırılabilir. Destekleme ve Yetiştirme Kurslarına yönelik idareci, öğrenci ve veli görüşlerine yönelik çalışmalar yapılabilir.

\section{KAYNAKÇA}

Akın, F. (2012). Okul içi ve okul dışı öğrenmelerin öğrenci başarısına etkisi (Yayımlanmamış yüksek lisans tezi). Mehmet Akif Ersoy Üniversitesi, Sosyal Bilimler Enstitüsü, Burdur.

Akkaya, A. (2017). Destekleme ve yetiştirme kurslarının öğrenci görüşlerine göre değerlendirilmesi (Yayımlanmamış yüksek lisans tezi). Ahi Evran Üniversitesi, Sosyal Bilimler Enstitüsü, Kurşehir.

Biber, A.Ç., Tuna, Abdulkadir, Polat, A.C., Altınok, F., \& Küçükoğlu, U. (2017). Ortaokullarda uygulanan destekleme ve yetiştirme kurslarına dair öğrenci görüşleri. Bayburt Eğitim Fakültesi Dergisi. 12 (23), 103-119.

Bingöl, T. (2017). Destekleme ve yetiştirme kurslarına katılan ortaokul öğrencilerinin spora katılım motivasyonlarının incelenmesi (Bitlis-Tatvan örneği) (Yayımlanmamış yüksek lisans tezi). Ahi Evran Üniversitesi, Sosyal Bilimler Enstitüsü, Kırşehir. 
Bozbayındır, F., \& Kara, M. (2017). Destekleme ve yetiştirme kurslarında (DYK) karşılaşılan sorunlar ve öğretmen görüşleri temelinde çözüm önerileri. Sakarya University Journal of Education, 7(2), 324-349.

Büyüköztürk, Ş. (2002). Faktör analizi: temel kavramlar ve ölçek geliştirmede kullanımı. Kuram ve Uygulamada Ë̆itim Yönetimi, 32, 470-483.

Büyüköztürk, Ş. (2012). Sosyal bilimler için veri analizi el kitabı (17. baskl). Ankara: Pegem Akademi.

Büyüköztürk, Ş., Kılıç Çakmak, E., Akgün, Ö. E., Karadeniz, Ş., \& Demirel, F. (2009). Bilimsel Araştırma Yöntemleri. Ankara: Pegem Akademi.

Canpolat, U. (2017). Destekleme ve yetiştirme kursları bağlamında sosyal bilgiler öğretmenleri, kurs merkezi yöneticileri ve öğrenci görüşleri: Eskişehir ili örneği (Yayımlanmamış yüksek lisans tezi). 19 Mayıs Üniversitesi, Samsun.

Canpolat, U., \& Köçer, M. (2017). Destekleme ve yetiştirme kurslarının TEOG bağlamında sosyal bilgiler öğretmenlerinin görüşlerine dayalı olarak incelenmesi. Anadolu Journal of Educational Sciences International, 7(1), 123-154.

Çokluk, Ö., Şekercioğlu, G., \& Büyüköztürk, Ş. (2010). Sosyal bilimler için çok değişkenli istatistik. Ankara, Pegem Yayıncılık.

Demir-Başaran, S., \& Narinalp Yıldız, N. (2017). Türkiye'de ortaokullarda uygulanan destekleme ve yetiştirme kurslarına ilişkin öğretmen görüşleri. International Journal Of Eurasia Social Sciences, 8(29), 1152-1173.

Dönmez, İ., Pekcan, N., \& Tekçe, M. (2016). Destekleme ve Yetiştirme Kurslarının yönetici, ögretmen ve ögrenci görüşlerine göre değerlendirilmesi. 25. Ulusal Eğitim Bilimleri Kongresi, İstanbul Kültür Üniversitesi, Antalya.

Ergün, M. (2017). Destekleme ve yetiştirme kurslarının yönetici, ögretmen, ögrenci görüşlerine göre değerlendirilmesi. Yayımlanmamış yüksek lisans tezi. Fırat Üniversitesi, Elazığ.

Field, A. P. (2009). Discovering statistics using SPSS: and sex and drugs and rock " $n$ " roll (3rd ed.). London: Sage publications.

Göksu, İ., \& Gülcü, A. (2016). Ortaokul ve liselerde uygulanan destekleme kurslarıyla ilgili öğretmen görüşleri. Bayburt Eğitim Fakültesi Dergisi, 11(1), 153-171.

Hock, M. F., Pulvers, K.A., Deshler, D. D., \& Schumaker, J. B. (2001). The effects of an after-school tutoring program on the academic performance of at-risk students and students with LD. Remedial and Special Education, 22(3), 172-186. 
Holloway, J. H. (1999). Extracurricular activities: The path to academic success?. Educational Leadership. 57(4), 87-88.

İncirci, A., İlğan, A., Sirem, Ö., \& Bozkurt, S. (2017). Ortaöğretim destekleme ve yetiştirme kurslarına ilişkin öğrenci görüşleri. Mehmet Akif Ersoy Üniversitesi Eğitim Fakültesi Dergisi, (42), 50-68.

Knifsend, C. A., \& Juvonen, J. (2017). Extracurricular activities in multiethnic middle schools: Ideal context for positive intergroup attitudes? Journal of Research on Adolescence, 27, 407-422.

Krajcik, J. S., \& Blumenfeld, P. C. (2006). Project-based learning, In K.R., Sawyer (Ed.), The Cambridge handbook of the learning sciences (pp. 317-333). New York: Cambridge University Press.

Lauver, S. C. (2002). Assessing the benefits of an after-school program for urban youth: An İmpact and process evaluation. Pennsylvania University. Erişim adresi: http://repository.upenn.edu/dissertations. Erişim tarihi: 20.Mart.2018.

Lee, C. J., Park, H. J., \& Lee, H. S. (2009). Shadow education systems, In G. Sykes, B. L. Schneider, \& D. N. Plank (Eds.), Handbook of educational policy research (pp. 901-919). New York: Routledge.

Lunenburg, F. C., \& Ornstein, A. O. (2008). Educational administration: Concepts and practices (5th ed.). Belmont, CA: Wadsworth/Cengage Learning.

Mahoney J. L., \& Cairns, R. B. (1997). Do extracurricular activities protect against early school dropout? Developmental Psychology, 33, 241-253. http://dx.doi.org/10.1037/00121649.33.2.241

Massoni, E. (2011). Positive effects of extra curricular activities on students. College of DuPage (ESSAI), 9(1), 84-87. Erişim adresi: http://dc.cod.edu/essai/vol9/iss1/27. Erişim tarihi: 20 Mart 2018.

MEB. (2016). Millı̂ Eğitim Bakanlığı Örgün ve Yaygın Eğitimi Destekleme ve Yetiştirme Kursları Yönergesi. Erişim adresi: https://www.meb.gov.tr/meb_iys_dosyalar/2014_10/01060217. Erişim tarihi: 26 Ocak 2018.

MEB. (2017) Örgün ve Yaygın Eğitimi Destekleme ve Yetiştirme Kursları Tanıtım Kitapçı̆̆ı. Erişim adresi: http://odsgm.meb.gov.tr/kurslar/dyk_kit.pdf. Erişim tarihi: 26 Ocak 2018.

Metsäpelto, R. L., \& Pulkkinen, L. (2012). Socioemotional behavior and school achievement in relation to extracurricular activity participation in middle childhood. Scandinavian Journal of Educational Research, 56(2), 167-182 
Miranda, J. Y. (2001). A study of the effect of school-sponsored, extra-curricular activities on high school students' cumulative grade point average, sat score, act score, and core curriculum subject grade point average. Unpublished doctoral dissertation. University of North Texas.

Nartgün, Ş. S., \& Dilekçi, Ü. (2016). Eğitimi destekleme ve yetiştirme kurslarına ilişkin öğrenci ve öğretmen görüşleri. Kuram ve Uygulamada Eğitim Yönetimi, 22(4), 537-564.

Resmi Gazete. (2010). Millı̂ Eğitim Bakanlığı Yaygın Eğitim Kurumları Yönetmeliği. Erişim adresi: http://www.resmigazete.gov.tr/main.aspx?home=http://www.resmigazete.gov.tr/eskiler/2010/0 5/20100521.htm\&main=http://www.resmigazete.gov.tr/eskiler/2010/05/20100521.htm.

Erişim tarihi: 26 Ocak 2018.

Millî Eğitim Bakanlığı Ortaöğretim Kurumları Yönetmeliği. (2013, 07 Eylül). Resmi Gazete (Sayı: 28758) Erişim adresi: http://www.resmigazete.gov.tr/eskiler/2013/09/20130907-4.htm

Millî Eğitim Bakanlığı Okul Öncesi Eğitim ve İlköğretim Kurumları Yönetmeliği. (2014, 26 Temmuz). Resmi Gazete (Sayı:29072). Erişim adresi: http://www.resmigazete.gov.tr.

Shernoff, D. J. (2010). Engagement in after school programs as a predictor of social competence and academic performance. American Journal Of Community Psychology, 45(3-4), 325-337.

Stoltzfus, C. D. (2007). A Study of the Correlation Between Participation in Extracurricular Activities and Academic Performance of Middle Level and High School Students. MApaper The Pennsylvania State University.

Tavşancıl, E. (2002). Tutumların ölçülmesi ve SPSS ile veri analizi. Ankara: Nobel Yayıncılık.

Uğurlu, F. (2017). Destekleme ve yetiştirme kurslarında görevli öğretmenlerin kurslara yönelik öz algl düzeylerinin incelenmesi (Ordu ili örneği) (Yayımlanmamış yüksek Lisans Tezi). Amasya Üniversitesi, Amasya.

Uğurlu, F., \& Aylar, F. (2017). Destekleme ve yetiştirme kurslarına yönelik öğretmen öz alg1 ölçeğinin geliştirilmesi: Geçerlik ve güvenirlik çalışması. Gazi Eğitim Bilimleri Dergisi, 3(1), $28-43$.

Ünsal, S., \& Korkmaz, F. (2016). Destekleme ve yetiştirme kurslarının işlevlerine ilişkin öğretmen görüşlerinin incelenmesi. KSÜ Sosyal Bilimler Dergisi, 13(12), 87-118.

\section{Extended Abstract}

During the education session, schools can develop and put into practice every kind of activities related to educational aims which were specified beforehand. Students can learn more provided that they are motivated in school which are capable of applying activities successfully. On the other hand, additional courses can be needed due to aims are not reached by students efficiently because of environmental and individual insufficiencies. 
Supporting and Training Courses, among the additional courses, are given in school without payment by state. Supporting and Training Courses started giving free educations according to regulation on Supporting and Training Courses published by Ministry of National Education on 23.09.2014. Number of regulation is 4145909 . Thoughts of teachers, who have been serving in the Supporting and Training Courses, can be used as data in developing success of these courses. Supporting and training courses for Turkish and Mathematics courses were opened for elementary school 3rd and 4th grade students in 12 pilot provinces and districts determined during the 2nd semester of 2017-2018 academic year. According to data shared by Ministry of National Education, 9 million students applied courses and 630.000 teachers served in Supporting and Training Courses in 2015-2016 education session. Both principals and teachers are encouraged by extra payments for these courses. However, being a new application causes inevitable problems. Developing solutions for problems will contribute success of Supporting and Training Courses. Also examining academic-individual contributions and social effects of Supporting and Training Courses can be helpful developing these courses. The main aim of this study is to examine attitudes of teachers who serve in state schools. This research is done using scanning model which is one of quantitative research methods. The population of the research consists of 4081 teachers working in 381 secondary schools in central districts (Bağlar, Yenişehir, Sur, Kayapınar) of Diyarbakır Province. The sample, according to study design, consists of 536 teachers who are working in secondary schools. The teachers were selected using "criterion sampling" which is one of the purpose sampling methods. Schools, in which Supporting and Training Courses continued, were determined in 4 central districts. Attitude scales were given 536 teachers. There were 435 scales in total after eliminating the scales which were not filled properly. "Attitude scales for Supporting and Training Courses", which was developed by researchers, was used to gather information about thoughts of teachers on Supporting and Training Courses. Factor analysis of attitude scale for Supporting and Training Courses was performed using Explanatory Factor Analysis and Confirmatory Factor Analysis. The scale consists of 3 factors- named Economic Support, Social Effects, Academic contributions- and 22 items. Finally, reliability coefficient was calculated as Alpha $=.90$. Data, obtained by study, was analyzed using AMOS and SPSS packet programs. The results of study have shown that attitude toward Economic Support is high, attitudes of teachers, students and families towards Social Effects are moderate, attitude of teachers and students toward Academic Contributions is considerably high. Another result, obtained from study, is there is no obvious connection between sex of teachers and their attitude toward Supporting and Training Courses. Yet, according to sex factor, general attitude toward Social Effects and Academic Contributions of female teachers is a little bit higher than male teachers. It is understood that age gap between teachers, who were subjected to study, does not affect attitudes toward the Supporting and Training Courses. Another result has shown that length of service also does not affect attitudes on the point of Academic Contributions, Social Effects and Economic Support.

However, attitude toward Academic Contributions differs from one branch to another. This attitude differences can be seen between teachers in Turkish, Mathematics, Science, Social Sciences, Foreign Language and teachers in Visual Arts, Music, Physical Education. 